\title{
The Mechanism of Action of Nitro-heterocyclic Antimicrobial Drugs. Metabolic Activation by Micro-organisms
}

\author{
By BETH P. GOLDSTEIN, RAMON R. VIDAL-PLANA, * \\ BRUNO CAVALLERI, LUIGI ZERILLI, GIULIANA CARNITI \\ AND LUIGI G. SILVESTRI $\dagger$ \\ Direzione Laboratori di Chemioterapia, Gruppo Lepetit S.p.A., Milan, Italy
}

(Received I4 December I976)

SUMMARY

\begin{abstract}
Although the target of the antimicrobial drug I-methyl-2-nitro-5-vinylimidazole (MEV) has been shown to be DNA (Goldstein et al., 1977) the drug was ineffective in cell-free systems because it was not activated. Both the rate of metabolic activation of MEV and its antibacterial activity were increased when bacteria were grown in limiting oxygen. Mutants of Escherichia coli which were conditionally resistant to nitroimidazoles and nitrofurans were defective in drug activation. The activities of these drugs against $E$. coli correlated with their rates of metabolism. The antimicrobial spectrum of the drugs appeared to be related to their reducibility by different species.
\end{abstract}

\section{INTRODUCTION}

I-Methyl-2-nitro-5-vinylimidazole (MEV) (Cavalleri et al., 1973) belongs to a class of drugs (including nitrofurans as well as nitroimidazoles) whose antimicrobial activity depends on the presence of the nitro group (Dann \& Möller, 1947; Grunberg \& Titsworth, 1973). Although members of this class of drugs differ in a number of properties including their spectrum of antimicrobial activity (Grunberg \& Titsworth, 1973; Edwards, Dye \& Carne, 1973), studies of the mechanism of action of nitrofurazone (McCalla, Reuvers \& Kaiser, 1970), metronidazole (Ings, McFadzean \& Ormerod, 1974) and MEV (Goldstein et al., I977) suggest that the effective target of all of these drugs is DNA.

It has been known for some time that nitro-organic compounds are reduced by microbial systems (Dann \& Möller, 1947) and, recently, reduced derivatives were shown to be reactive and to bind to DNA and to proteins (McCalla et al., 1970; Ings et al., 1974; Tu \& McCalla, 1975). In this paper, we show that metabolic activation (reduction of the nitro group) necessarily accompanies the bactericidal effects of MEV. We also provide evidence that the spectra of activity of nitroimidazoles and nitrofurans are determined, in part, by whether the target organism grows at a redox potential consistent with the generation of reactive reduction products.

\section{METHODS}

Antibiotics and chemotherapeutic agents. The nitroimidazoles and aminoimidazoles listed in Table I were synthesized at Lepetit by the methods cited. Metronidazole and streptomycin were obtained from Farmitalia (Milan, Italy); nitrofurazone, nitrofurantoin, nitro-

* Present address: Rotta Research, San Fruttuoso di Monza (Milan), Italy.

$\dagger$ Present address: Cattedra di Microbiologia, Università di Roma, Italy. 
Table I. Structures of nitroimidazoles and aminoimidazoles studied

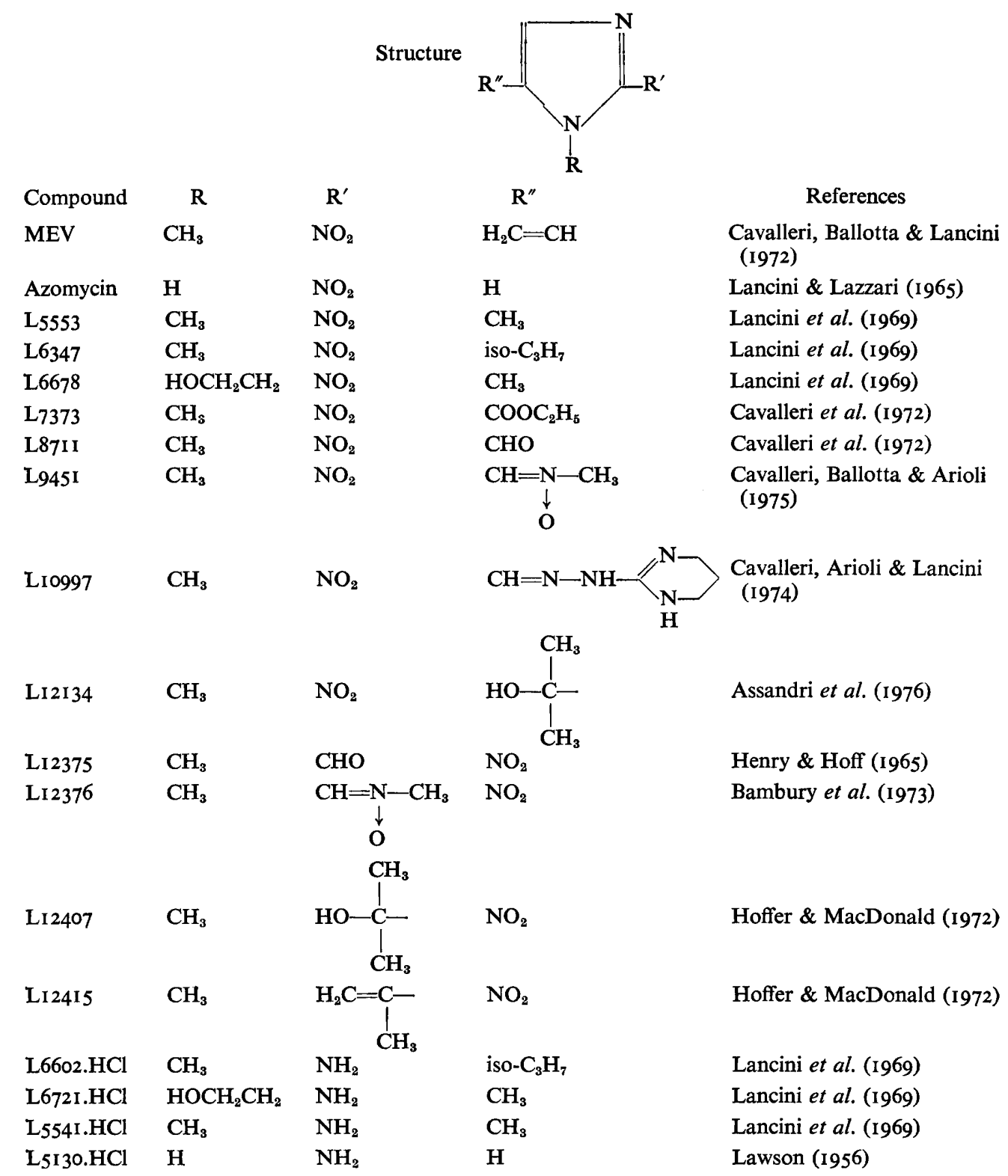

furaltadone, furazolidone, nalidixic acid, tetracycline and kanamycin from Prodotti Gianni (Milan, Italy); and mitomycin $\mathrm{C}$ from Sigma. Chloramphenicol and rifampicin are produced by Lepetit (Milan, Italy).

Bacteriophages and bacteria. Coliphage $\lambda$ strains, $\mathrm{T}_{4}$ bo5 and $\phi 80 p s u I I I^{+}$(which carries the coli amber suppressor $t y r T$ ) were obtained from W. F. Dove. PI $C m$ was from M. Iaccarino and T6 from N. Willets. Escherichia coli strain L47 (= SKFI 2140) was obtained from Smith, Kline \& French Laboratories (Philadelphia, U.S.A.). Escherichia coli KI2 
Table 2. Strains of E. coli KI2 used

\begin{tabular}{|c|c|c|}
\hline $\begin{array}{l}\text { Lepetit } \\
\text { no. }\end{array}$ & $\begin{array}{l}\text { Common } \\
\text { name }\end{array}$ & $\begin{array}{l}\text { Relevent } \\
\text { genotype }\end{array}$ \\
\hline L333 & AT9I5 & Hfr KLI6 \\
\hline L674 & АT978 & Hfr KLI6 \\
\hline L354 & JC2926 & $\operatorname{recAI} 3$ \\
\hline L694 & JC2879 & $\begin{array}{l}\mathrm{F}^{-} \text {leu proA lac gal his tsx } \\
\text { supE str }\end{array}$ \\
\hline L699 & & L694 thy \\
\hline L490 & R90I & chlA chlD \\
\hline L7I 4 & Puig442 & chlB2 \\
\hline 1716 & C26 & $\operatorname{chlE5}$ \\
\hline 1725 & Puig426 & $\operatorname{chl} C_{3}$ \\
\hline $\mathbf{L} 620$ & NIO7I & $\operatorname{trp} p_{a m}$ galK $K_{a m}$ galE \\
\hline L523 & KLI 699 & Hfr KLI6 recAI thy ${ }^{+}$ \\
\hline $\mathbf{L 7 3 7}$ & & L620 $\left(\phi 80 p s u I I I^{+}\right)$ \\
\hline L710 & & $\mathbf{L 6 9 9}(\lambda h)$ \\
\hline $\mathbf{L 7 3 0}$ & & L710 $n d r-3$ \\
\hline $\mathbf{L} 740$ & & L7IO recAI thy $y^{+}$, non-lysogen \\
\hline L744 & & L730 recAI thy ${ }^{+}$, non-lysogen \\
\hline L739 & & L730 non-lysogen \\
\hline L69I & & L333 ndr-IOI \\
\hline $\mathbf{L 7 0 0}$ & & $\begin{array}{l}\text { L694 } \mathrm{pro}^{+} \mathrm{lac}^{+} \mathrm{gal}^{+} \mathrm{sup}^{+} \mathrm{tsx} \mathrm{x}^{+} \\
\text {ndr-IOI }\end{array}$ \\
\hline L7II & & L700 (PI Cm) \\
\hline L726 & & L674 ndr-15o \\
\hline
\end{tabular}

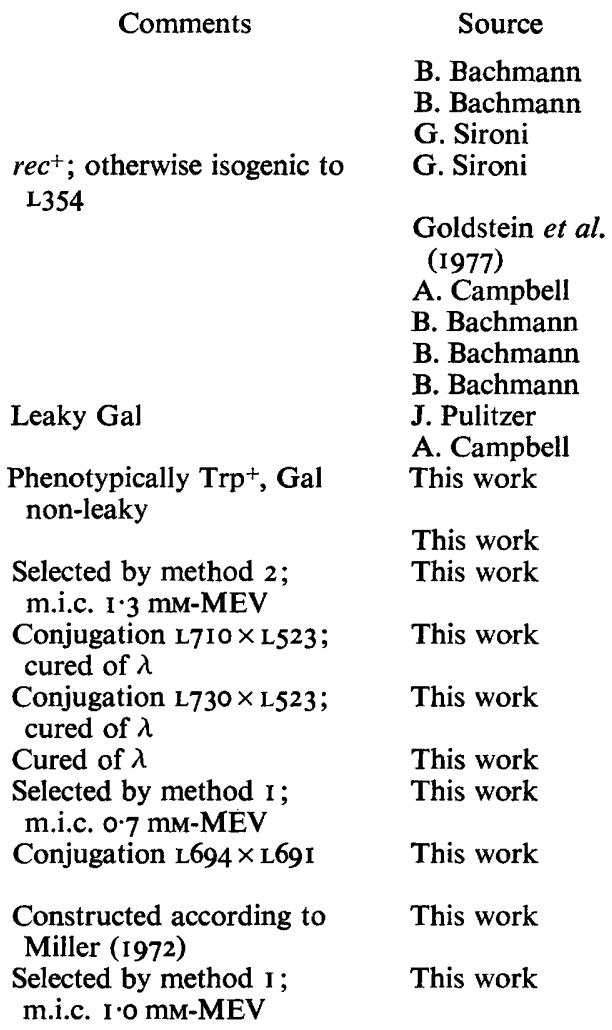

strains used are described in Table 2. Strains cured of $\lambda$ were obtained by screening survivors after $\lambda$ imm2r $b 2$ infection of lysogens.

Growth conditions. Unless otherwise indicated, E. coli strains were cultured and treated in EM9 medium (Clark et al., I966) at $37^{\circ} \mathrm{C}$.

Drug sensitivity. Minimal inhibitory concentrations (m.i.c.) for $E$. coli $\mathrm{KI} 2$ strains were determined as described by Goldstein et al. (1977). For strain L47, the same procedure was used except that bacteria were grown in Penassay broth (Difco). M.i.c. for Trichomonas vaginalis (strain obtained from I. De Carneri) were determined as described by Cavalleri, Ballotta \& Arioli (I97I).

DNA synthesis in toluene-treated bacteria. Bacteria were treated with toluene and assayed as described by Kohiyama \& Kolber (1970). $\left[{ }^{3} \mathrm{H}\right] \mathrm{dTTP}$ (specific activity $28 \mathrm{Ci} \mathrm{mmol}^{-1}$ ) was purchased from The Radiochemical Centre, Amersham. Unlabelled deoxynucleoside and nucleoside triphosphates were from Sigma. ATP was present in the incubation mixture.

Metabolism of drugs. Spectrophotometric measurements of nitro-drugs were made on extracellular medium obtained by filtration (Millipore, HAWP) or by centrifugation of treated cultures. The ultraviolet (u.v.) absorption maxima for the drugs were: MEV, $365 \mathrm{~nm}$; nitrofurazone, $375 \mathrm{~nm}$; azomycin, $370 \mathrm{~nm}$; and metronidazole, $320 \mathrm{~nm}$.

$\left[2-{ }^{14} \mathrm{C}\right] \mathrm{MEV}$ (specific activity $0.37 \mathrm{Ci} \mathrm{mol}^{-1}$ ) was synthesized by $\mathrm{G}$. Sartori. Its uptake by $E$. coli was estimated from the radioactivity retained by Millipore filters. Extracellular radioactivity was measured in the supernatant fluids after centrifugation. Samples of cultures 
were also precipitated in cold $5 \%(\mathrm{w} / \mathrm{v})$ trichloroacetic acid (TCA) and assayed for precipitable (retained by Sartorious SMI 3400 glass fibre filters) and for soluble (supernatant fluid after centrifugation) radioactivity. The radioactivities of the supernatant fluids ( $\mathrm{m} \mathrm{ml}$ samples) and Millipore filters were measured in Io $\mathrm{ml}$ Dimilume (Packard); and those of glass fibre filters were measured in $10 \mathrm{ml}$ toluene-based scintillation mixture $[5.5 \mathrm{~g}$ Permablend I (Packard) per 1 toluene].

The extracellular medium was further analysed by thin-layer chromatography. Samples ( $\mathrm{I} \mathrm{ml}$ ) were lyophilized, resuspended in $0.2 \mathrm{ml}$ distilled water, and applied to $0.25 \mathrm{~mm}$ thick silica gel F254 plates (Merck). They were run for approximately $18 \mathrm{~cm}$ in solvent system A (chloroform/methanol, 9: $\mathrm{I}, \mathrm{v} / \mathrm{v}$ ). In some cases, material remaining at the origin was scraped off, extracted with $3 \mathrm{ml}$ methanol/water ( $\mathrm{I}: \mathrm{I}, \mathrm{v} / \mathrm{v}$ ), lyophilized, dissolved in $0 . \mathrm{I} \mathrm{ml}$ water and re-run in solvent system $B$ (methanol/ acetic acid, 95: I, v/v). The radiochromatograms were scanned on a Packard Model $720 \mathrm{r}$ radioscanner at a rate of $0.5 \mathrm{~cm} \mathrm{~min}^{-1}$.

Effect of growth conditions on MEV activity. The bactericidal effect of MEV, and DNA degradation induced by MEV, were determined as described by Goldstein et al. (1977). Redox potentials of cultures (relative to a standard calomel electrode) were followed with an Amel $\mathrm{pH}$ meter which, when equipped with a platinum electrode, functioned as a potentiometer.

Selection of MEV-resistant (ndr) mutants. Method I (training). Subcultures in NB (Oxoid no. 2 nutrient broth) containing different concentrations of MEV were grown with vigorous aeration to apparent saturation and observed microscopically. The culture with the highest drug concentration which had good growth and a majority of normal sized (nonfilamentous) cells was used to inoculate broths containing higher concentrations of MEV. Bacteria were never stored in the presence of the drug. When the desired level of resistance was obtained, cultures were cloned and the m.i.c. of the isolates were checked.

Method 2. Bacteria lysogenic for $\lambda$ (strain L7IO) were incubated in TM buffer (0.01 MTris plus $0.01 \mathrm{M}-\mathrm{MgSO}_{4}, \mathrm{pH} \mathrm{8.0)}$ for Io min with $13 \mathrm{~mm}-\mathrm{MEV}$. The bacteria were washed and diluted 20-fold (to about $10^{7}$ bacteria $\mathrm{ml}^{-1}$ ) in Tryptone broth (Difco) supplemented with $25 \mu \mathrm{g}$ thymine $\mathrm{ml}^{-1}$ and grown to saturation. The culture was challenged with $\lambda c I_{72}$, to eliminate non-lysogens, and cloned on NB agar containing thymine and 0.07 mM-MEV.

Mapping of ndr mutants. Mutations selected in the Hfr strains L333 and L674 were mapped by conjugation with $\mathrm{L} 694$; $n d r-3$ which was selected in an $\mathrm{F}^{-}$strain (L7IO) was conjugated with L674. Pro $^{+}$Str recombinants were selected on Davis agar (Davis \& Mingioli, I950) containing $0 \cdot \mathrm{I} \mathrm{mg}$ streptomycin $\mathrm{ml}^{-1}$. Recombinants were scored for the unselected markers his, gal, lac, leu and $n d r$ by replicating to appropriate media and for $t s x$ and sup by spot tests with bacteriophages T6 and $\lambda$ susO29.

A PI lysate, obtained by heat induction of L7II (ndr-IOI), was used to transduce 2737 . $\mathrm{Gal}^{+}$recombinants were selected and scored for $n d r$. Conjugations and transductions were performed as described by Miller (1972).

Polarographic analysis. We prepared solutions containing approximately $40 \mu \mathrm{g} \mathrm{drug} \mathrm{m}^{-1}$ in methanol/I M-sodium acetate buffer $\mathrm{pH} 5.4(\mathrm{I}: \mathrm{I}, \mathrm{v} / \mathrm{v})$. The solution, at $25^{\circ} \mathrm{C}$, was placed in a polarographic cell, which consisted of a mercury drop electrode, a saturated calomel electrode and a saturated $\mathrm{KNO}_{3}$ bridge. Oxygen was expelled by bubbling with nitrogen for about $10 \mathrm{~min}$. The polarogram was recorded from 0.0 to $-\mathrm{I} \cdot 7 \mathrm{~V}$ with a Beckman Electroscan 30 polarograph. The reduction waves were measured by the method of tangents. The $E_{\frac{1}{2}}$ values reported are due to the first reduction wave of the nitro group and represent the potential at which reduction to the hydroxylamine is $50 \%$ complete (Kolthoff \& Lingane, I952; Brezina \& Zuman, 1958). 


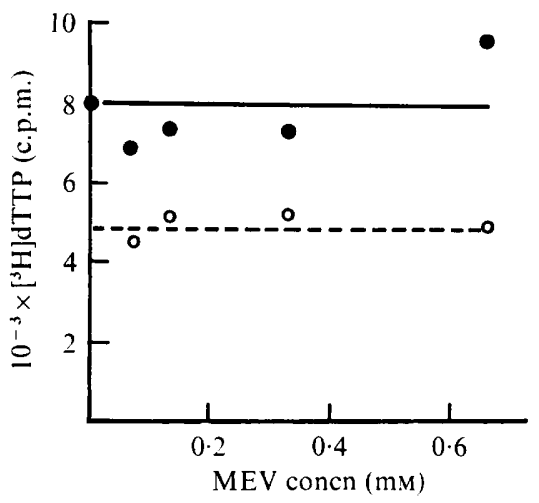

Fig. I. Effect of MEV on DNA synthesis in toluene-treated E. coli. Strain L694 was treated with toluene and incubated in the presence of various concentrations of MEV for $10(\bigcirc)$ or $20(\Theta) \mathrm{min}$.

Table 3. Metabolism and uptake of $\left[{ }^{14} \mathrm{C}\right] \mathrm{MEV}$ by E. coli

The experiment was done using a culture of strain L694 which had an extinction

\begin{tabular}{|c|c|c|c|c|c|c|}
\hline \multirow{2}{*}{$\begin{array}{c}\text { Time } \\
\text { after } \\
\text { MEV } \\
\text { addition } \\
\text { (min) }\end{array}$} & \multicolumn{2}{|c|}{$E_{565}$} & \multicolumn{4}{|c|}{ Radioactivity [c.p.m. (ml culture) $\left.{ }^{-1}\right]$ in : } \\
\hline & Medium & $\begin{array}{l}\text { TCA- } \\
\text { soluble }\end{array}$ & Cells & Medium & $\begin{array}{c}\text { TCA- } \\
\text { precipitable }\end{array}$ & $\begin{array}{c}\text { TCA- } \\
\text { soluble }\end{array}$ \\
\hline 0 & 0.459 & 0.406 & 742 & 23800 & 126 & 22300 \\
\hline I 5 & 0.335 & 0.306 & IOIO & 20800 & 364 & 22200 \\
\hline 30 & 0.234 & 0.212 & 884 & 20800 & 463 & 22400 \\
\hline 45 & 0.184 & 0.152 & 810 & 19900 & 527 & 21000 \\
\hline 60 & 0.113 & 0.094 & 706 & 23100 & 549 & 22200 \\
\hline 90 & 0.078 & 0.034 & 800 & 23500 & 585 & 21700 \\
\hline
\end{tabular}

RESULTS AND DISCUSSION

Inactivity of $M E V$ in cell-free systems

We have demonstrated that the antibacterial effect of MEV is due to induction of damage in DNA (Goldstein et al., I977). Concentrations as low as $3 \mu \mathrm{M}$ were bactericidal for rec $A$ strains of $E$. coli and Io-fold higher concentrations induced prophage $\lambda$ and mutations in wild-type strains (Goldstein et al., 1977). However, extracellular bacteriophage T4bo5 (a highly permeable mutant, obtained from S. Benzer) was completely resistant to incubation with up to $3.3 \mathrm{mM}-\mathrm{MEV}$ for I h (data not shown). DNA from Bacillus subtilis had $100 \%$ transforming ability after incubation in vitro with $0.33 \mathrm{mM}-\mathrm{MEV}$ for $30 \mathrm{~min}$, while DNA extracted from treated bacteria was only I $3 \%$ as efficient as an equivalent amount of DNA from untreated bacteria (Mastromei \& Riva, personal communication).

RNA synthesis in intact $E$. coli was blocked within $30 \mathrm{~min}$ by $0.33 \mathrm{~mm}-\mathrm{MEV}$, while 6.7 mM-MEV did not inhibit cell-free RNA synthesis, assayed by the method of Burgess (1969). In a non-agitated culture, $0.03 \mathrm{mM}-\mathrm{MEV}$ inhibited DNA synthesis by 40 to $80 \%$ over the first 20 min of treatment (unpublished data). However, $\left[{ }^{3} \mathrm{H}\right] \mathrm{dTTP}$ incorporation by toluene-treated bacteria of the same strain was not inhibited by up to $0.67 \mathrm{~mm}$-MEV (Fig. I). Saeki et al. (I974) had observed that the related drug azomycin likewise inhibited polynucleotide synthesis only in intact cell systems.

A possible explanation for the lack of activity of MEV in cell-free systems is that it must 


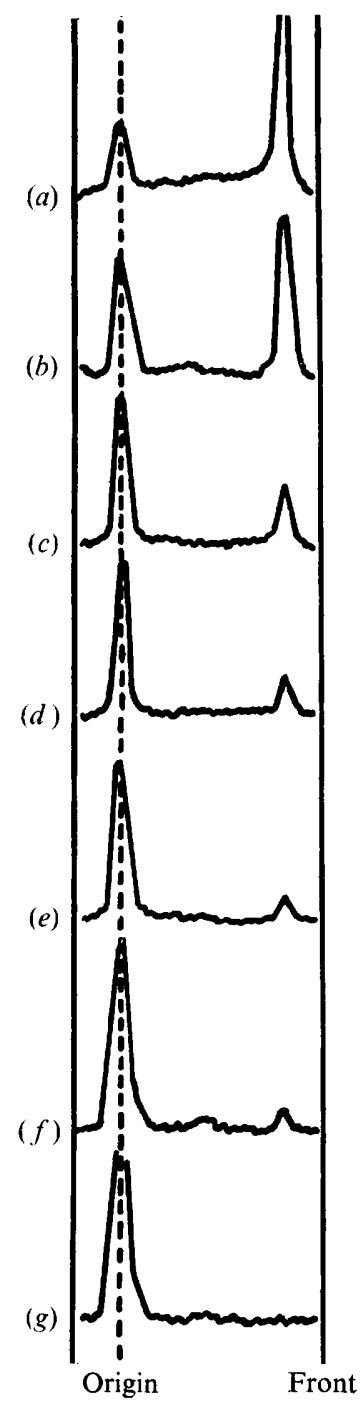

Fig. 2

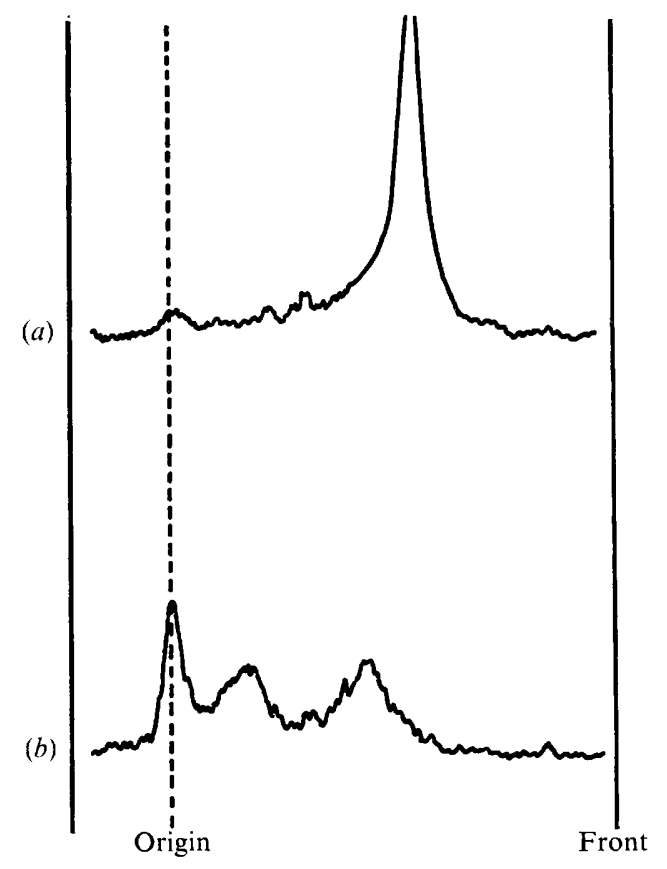

Fig. 3

Fig. 2. Chromatography of cell-free medium in solvent system A. (a) Control, MEV in EM9 medium; ( $b$ to $g$ ) after MEV had been in contact with $E$. coli for (min): (b) 0; (c) 15; (d) 30; (e) 45; (f) $60 ;(g) 90$.

Fig. 3. Chromatography of cell-free medium in solvent system B. (a) Control, MEV in EM9 medium; (b) rechromatography of material at the origin in Fig. $2(g)$.

be activated by a metabolic process. McCalla et al. (1970) found that the inactivity of nitrofurazone in cell-free systems was remedied by enzymic or electrochemical reduction of the drug. As several nitro-heterocyclic compounds can be reduced by micro-organisms (Beckett \& Robinson, 1956, 1959; Cartwright \& Cain, 1959; McCalla et al., 1970) this represents a probable pathway for metabolic activation. 

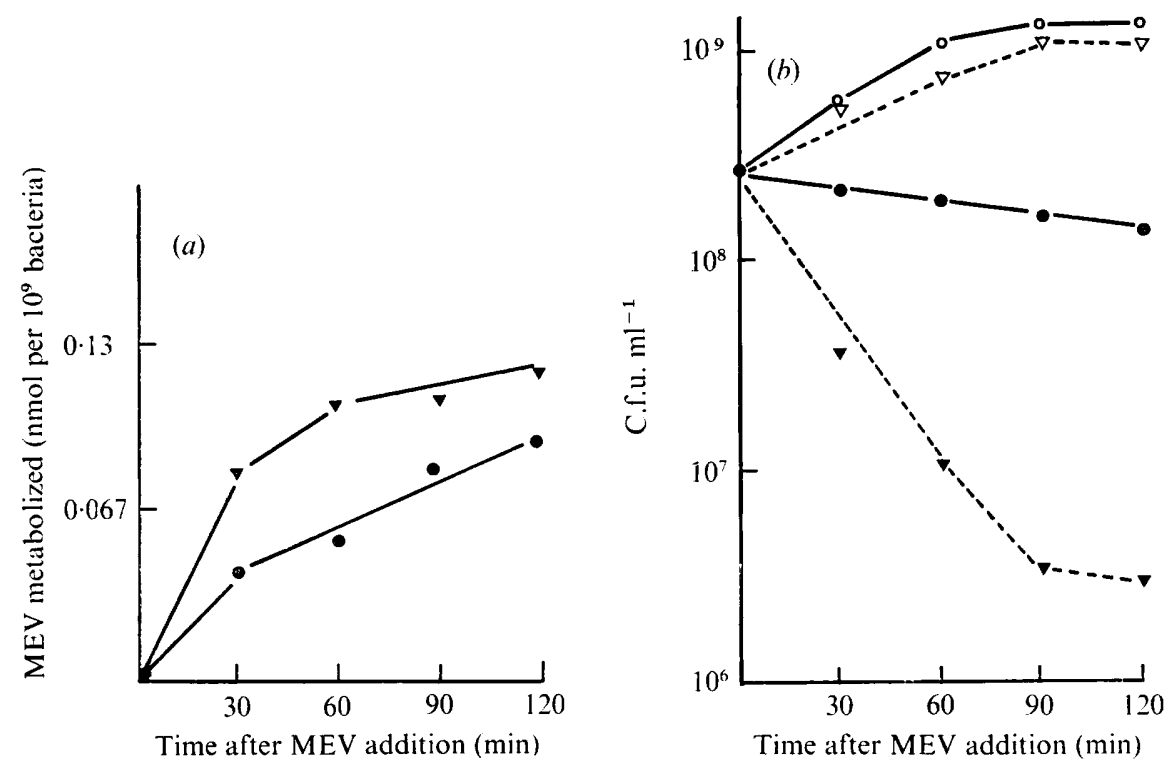

Fig. 4. Effect of agitation on MEV metabolism and activity. A culture of E. coli strain L694 was grown, with agitation, to an extinction $\left(E_{590}\right)$ of 0.5 and divided. Growth was continued either with $(O, O)$ or without $(\nabla, \nabla)$ agitation, in the presence $(0, \nabla)$ or absence $(O, \nabla)$ of $0 \cdot 2$ mM-MEV. (a) Amount of MEV metabolized per $10^{9}$ bacteria. (b) Bactericidal effect of MEV.

\section{Metabolism of MEV by E. coli}

As shown in Table 3, when $\left[{ }^{14} \mathrm{C}\right] \mathrm{MEV}$ was added to a culture of $E$. coli, $80 \%$ of the drug (measured spectrophotometrically at $365 \mathrm{~nm}$, the absorption maximum when the nitro group is present) disappeared from the medium and from the cold TCA-soluble fraction in $90 \mathrm{~min}$. This was not due to uptake of the drug by the bacteria as almost all of the radioactivity remained in the TCA-soluble and extracellular fractions. At all times, approximately $4 \%$ of the labelled material appeared to be cell-associated (retained by Millipore filters). TCA-precipitable radioactivity increased with time to a maximum of about $3 \%$.

Chromatography of the medium showed loss of radioactivity from the MEV peak and the appearance of new, more polar radioactive compounds. In solvent system A, MEV had an $R_{H^{\prime}}$ value of 0.87 . In the presence of EM9 medium, about $30 \%$ remained at the origin (Fig. 2, trace $a$ ). On incubation with $E$. coli, material was progressively lost from the MEV peak (traces $b$ to $g$ ). In solvent system B, the presence of EM9 did not affect the migration of MEV, which had an $R_{F}$ value of 0.66 (Fig. 3, trace $a$ ). We therefore re-ran the material at the origin of the chromatogram in Fig. $2(\mathrm{~g})$ (90 min of contact with bacteria) in system B (Fig. 3, trace $b$ ). The results confirmed that MEV had essentially disappeared by this time and had been replaced by three compounds with $R_{F}$ values of $0.0,0.21$ and 0.56 . This behaviour was consistent with the properties of reduced nitroimidazoles which, in our experience, remain at the origin in solvent system $\mathrm{A}$ but run in solvent $\mathrm{B}$.

\section{Evidence that MEV metabolism is required for activity}

Effect of growth conditions on MEV metabolism and activity. MEV disappeared from the medium only in conditions in which it was effective. We never detected spontaneous disappearance of MEV from bacteria-free medium; nor was it metabolized by toluene-treated bacteria, whose reducing capacity is reportedly defective (Brown, Wisseman \& Matsushita, 

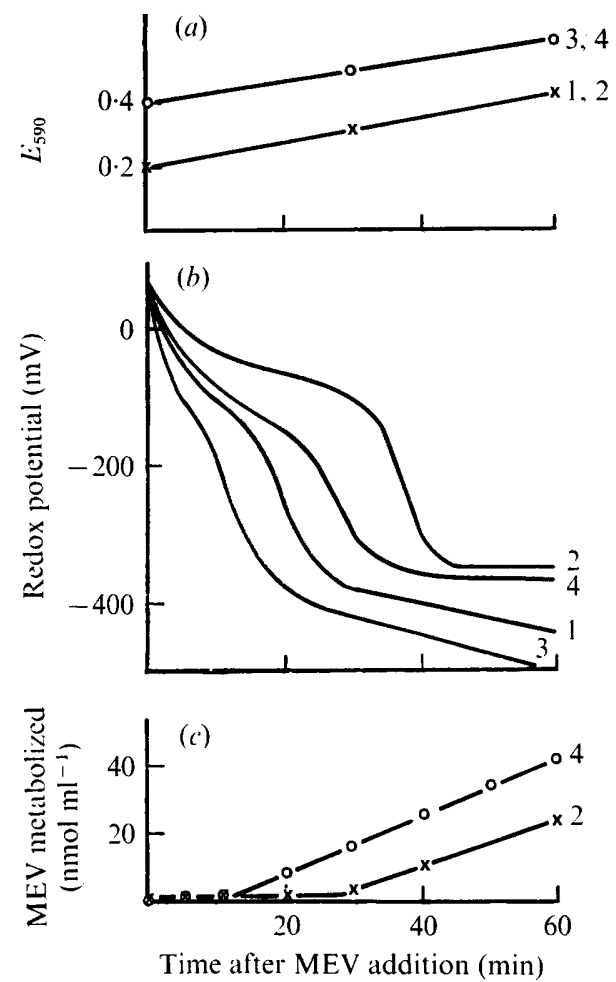

Fig. 5. Effect of cell density of cultures of E. coli on MEV metabolism. Two cultures of strain L694, one with $E_{590}=0.2(\times)$ and the other with $E_{590}=0.4(O)$, were divided: one half of each culture was treated with $0.1 \mathrm{mM}-\operatorname{MEV}(2,4)$; the other halves were left untreated $(I, 3)$. All cultures were placed under a layer of liquid Vaseline and stirred magnetically with the minimum agitation required to ensure uniformity of the cultures. $(a) E_{590} ;(b)$ redox potentials of the cultures; (c) MEV metabolism in the two treated cultures.

1972). In $E$. coli cultures, the rate of MEV metabolism varied inversely with the degree of aeration. Figure $4(a)$ shows that a culture of $E$. coli incubated without agitation metabolized MEV more rapidly than an agitated culture. The bactericidal effect of MEV was much more pronounced in the non-agitated culture (Fig. $4 b$ ).

The observed difference between agitated and non-agitated cultures seemed to reflect the availability of oxygen, as the extinction of the cultures also influenced the response to MEV treatment. Two cultures, differing only in extinction, each began to metabolize MEV when the redox potential of the medium dropped to about - I00 $\mathrm{mV}$. As the redox potential dropped more rapidly in the denser culture, MEV metabolism began sooner in this culture (Fig. 5). The onset of the bactericidal effect corresponded in time with the onset of MEV metabolism (data not shown). The presence of MEV retarded the drop in redox potential of treated cultures (Fig. $5 b$ ); this phenomenon was observed by Cramer (1947) for nitrofurazone and was called 'poising'.

Besides its bactericidal effect, other effects of MEV were more pronounced under conditions of reduced aeration: (i) $0.17 \mathrm{mM}-\mathrm{MEV}$, when added to a dilute agitated culture, blocked DNA synthesis after a lag of $30 \mathrm{~min}$; dense non-agitated cultures did not show this lag (data not shown). (ii) $\left[{ }^{14} \mathrm{C}\right] \mathrm{MEV}$ uptake into cold TCA-precipitable material was greater in non-agitated than in agitated cultures (Fig. 6a). (iii) DNA was degraded more rapidly, after MEV addition, in denser cultures (Fig. $6 b$ ). 

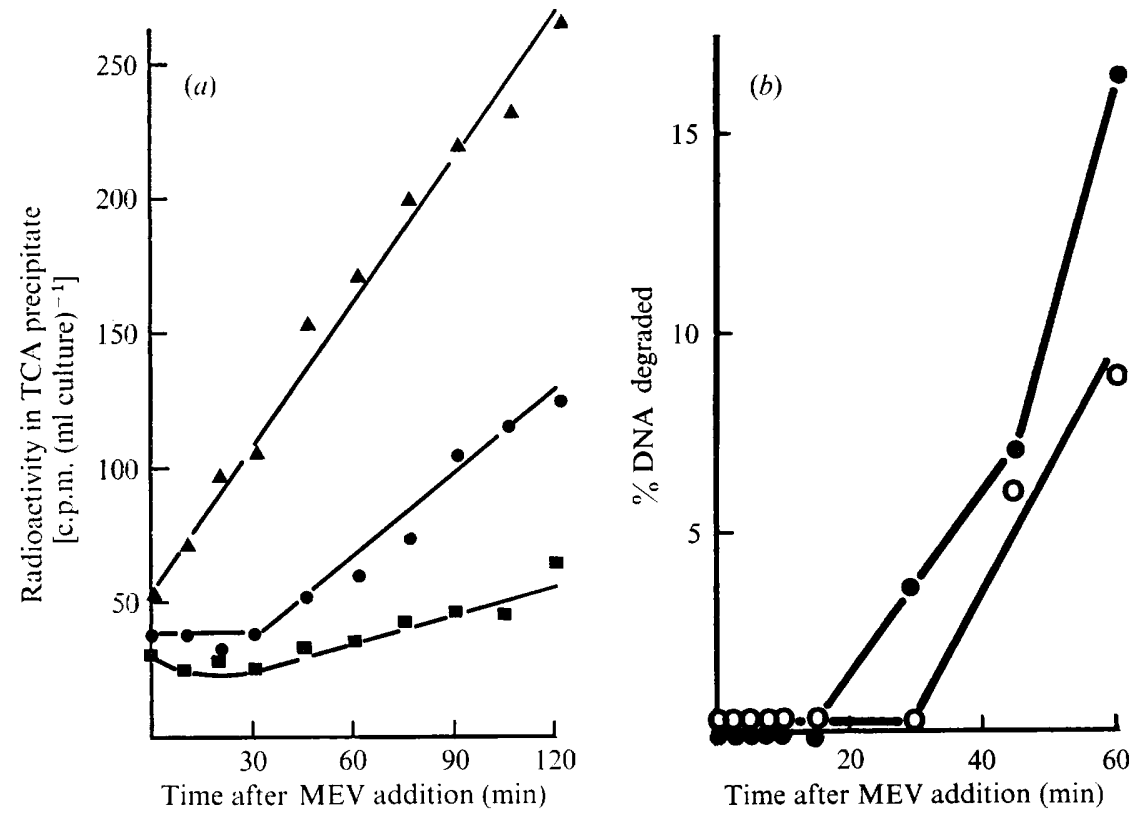

Fig. 6. Effect of aeration on MEV activity in E. coli. (a) Incorporation of $\left[{ }^{14} \mathrm{C}\right] \mathrm{MEV}(0.03 \mathrm{mM}$ added) into TCA-precipitable material in strain L694, grown with (O) or without $(\mathbf{A})$ agitation, and in

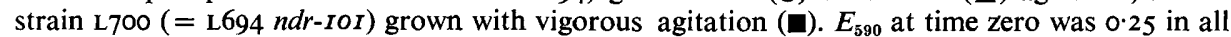
cultures. (b) A culture of strain $\mathrm{L694}$, prelabelled with $\left[{ }^{3} \mathrm{H}\right]$ thymidine, was grown with moderate agitation. Samples were treated with $0.2 \mathrm{mM}-\mathrm{MEV}$ when the extinction $\left(E_{590}\right)$ reached $0.05(O)$ and $0.25(\odot)$. DNA degradation was calculated from the radioactivity in the TCA-soluble fraction.

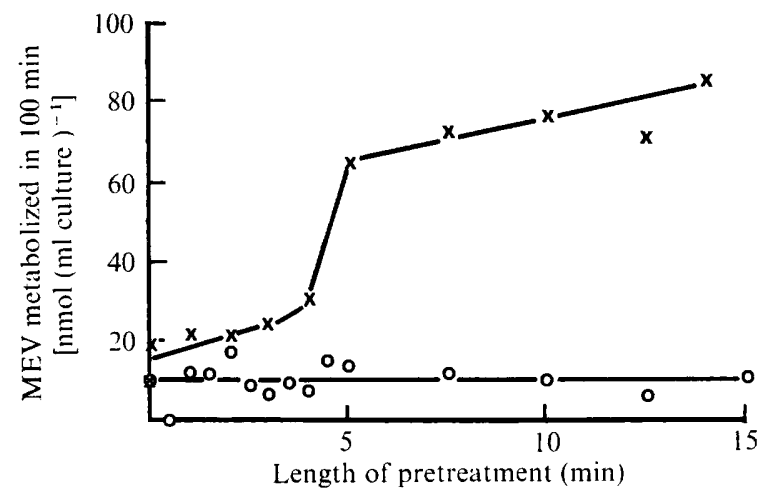

Fig. 7. Induction of MEV reductase by substrate. Escherichia coli strain L694 was pretreated for various times, with agitation, with either $100 \mu \mathrm{g}$ chloramphenicol $\mathrm{ml}^{-1}(O)$ or with $0.1 \mathrm{mM}-\mathrm{MEV}$ $(\times)$, and then incubated in static conditions with $0.1 \mathrm{~mm}-\mathrm{MEV}$ and $\mathrm{I} 00 \mu \mathrm{g}$ chloramphenicol $\mathrm{ml}^{-1}$ for $100 \mathrm{~min}$. MEV metabolism was normalized to cell density.

The close correlation between the extent of metabolism of MEV and its activity, suggest that the drug must be activated by cellular metabolism in order to be effective. The apparent inhibition and/or repression by oxygen of MEV metabolism is consistent with its activation by reduction. Inorganic nitrate reductase activities of bacteria are similarly affected by oxygen (Wimpenny \& Cole, 1967). As is the case for inorganic nitrate (Wimpenny \& Cole, 1967), MEV metabolism was also induced by substrate. As shown in Fig. 7, pre-incubation 

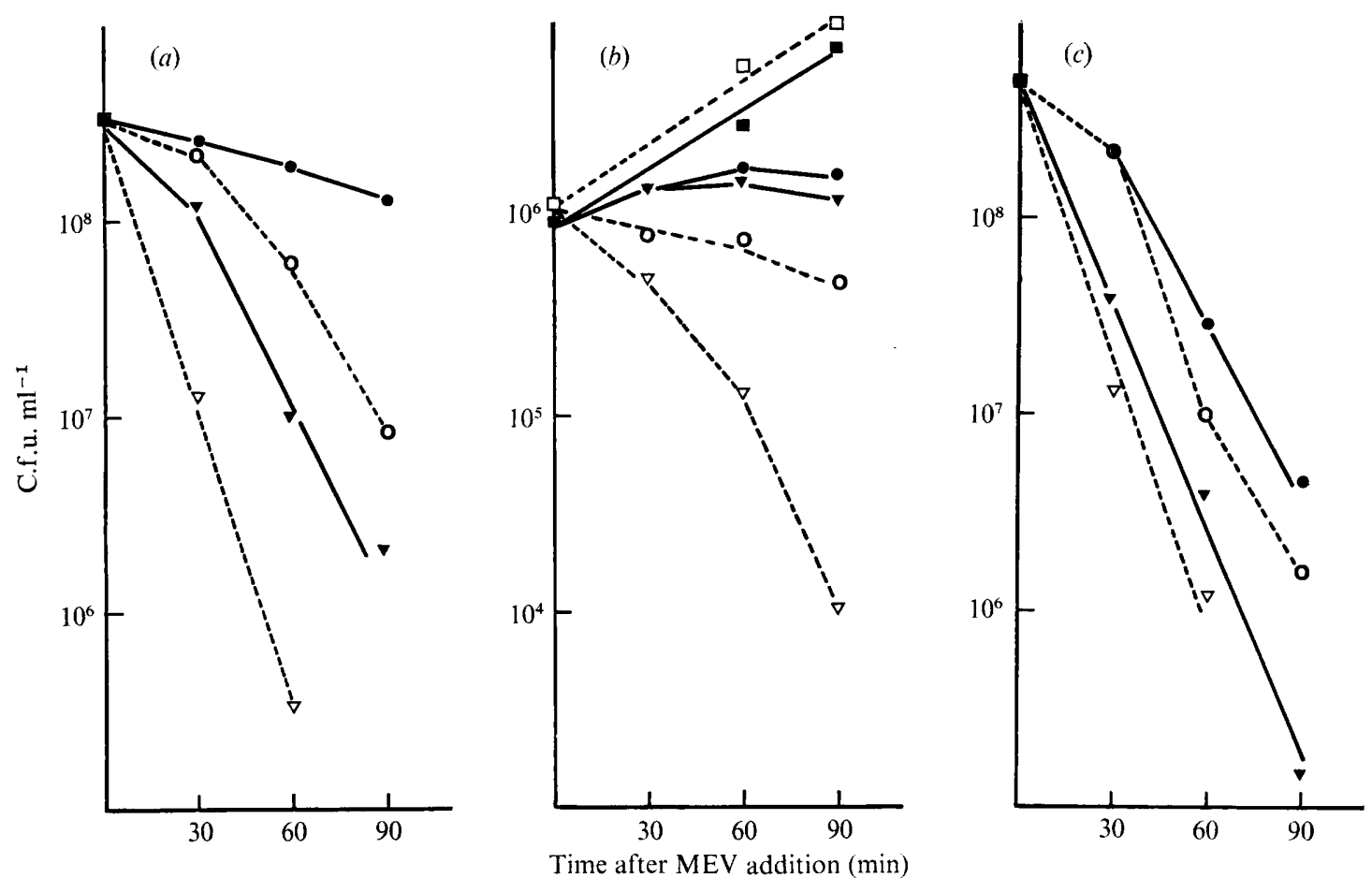

Fig. 8. Effect of culture conditions on expression of $n d r$. Escherichia coli strains L694 (sensitive strain; dashed lines and open symbols) and L700 (= L694 ndr-IOI; solid lines and symbols) were incubated; $(a)$ at high cell density with limited aeration provided by a magnetic stirrer; $(b)$ at low cell density without aeration; and $(c)$ at high cell density without aeration. $\square, \square$, Untreated or zero-time controls; $\odot, O$, addition of $0.2 \mathrm{mM}-\mathrm{MEV} ; \nabla, \nabla$, addition of $0.8 \mathrm{mM}-\mathrm{MEV}$.

of bacteria with MEV (aerated culture) for 4 min or longer led to an increased rate of MEV metabolism on subsequent incubation in the presence of chloramphenicol without agitation. As this experiment was performed with whole cells, the increase in activity could represent induction of either a permease or a reductase.

Characteristics of resistant mutants. MEV-resistant ( $n d r)$ mutants were difficult to select. Direct plating on various concentrations of the drug yielded mutants with levels of resistance only about three times that of the wild type; small colonies which appeared at higher concentrations were non-viable. In liquid cultures containing moderate levels of the drug and high cell inocula, growth of surviving sensitive cells occurred, apparently after MEV had been completely metabolized to an inactive form. At drug concentrations high enough to prevent this, there were no survivors.

Mutants with high levels of resistance (Io to 40 times the parental m.i.c. of $0.03 \mathrm{mM}$ ) were obtained in one of two ways: by serial subculture in broth containing increasing MEV concentrations (method I) or by brief exposure of a $\lambda$-lysogen to high levels of MEV (method 2). Method 2 took advantage of the fact that sublethal doses induced $\lambda$ (Goldstein et al., 1977); thus, enrichment for highly resistant lysogens could be achieved by relatively mild treatment and the mutants could be selected by plating on low levels of MEV. The mutants obtained by both procedures were conditionally resistant. While they showed a survival advantage on MEV treatment in agitated cultures (Fig. $8 a$ ) or at low cell density (Fig. $8 b$ ), they were barely distinguishable from the parental strains when treated at high 
Table 4. Resistance of an ndr strain to nitroimidazoles, nitrofurans and other drugs

Strain L69I is an $n d r$ derivative (ndr-IOI) of strain L333. Similar results were obtained with other $n d r$ mutants.

\begin{tabular}{|c|c|c|c|}
\hline & M.i.c. L69I & & M.i.c. L69I \\
\hline Nitro-drug & $\overline{\text { M.i.c. L333 }}$ & Other drug & M.i.c. L333 \\
\hline MEV & 20 & Nalidixic acid & I \\
\hline Nitrofurazone & 10 & Mitomycin C & I \\
\hline Nitrofurantoin & IO & U.v. light & I \\
\hline Furazolidone & 10 & Tetracycline & I \\
\hline Nitrofuraltadone & $>5$ & Kanamycin & I \\
\hline Azomycin & 5 & Rifampicin & I \\
\hline & & Chloramphenicol & I \\
\hline
\end{tabular}

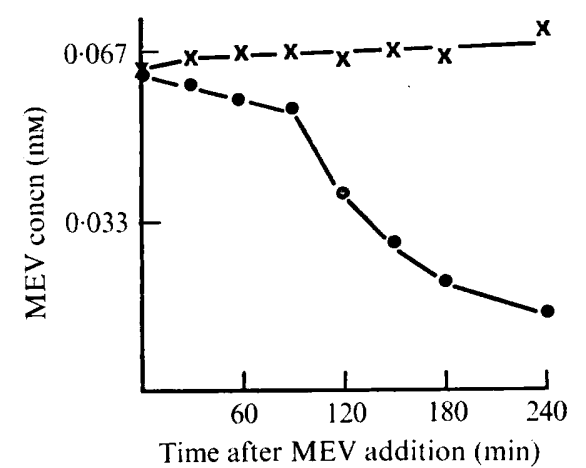

Fig. 9

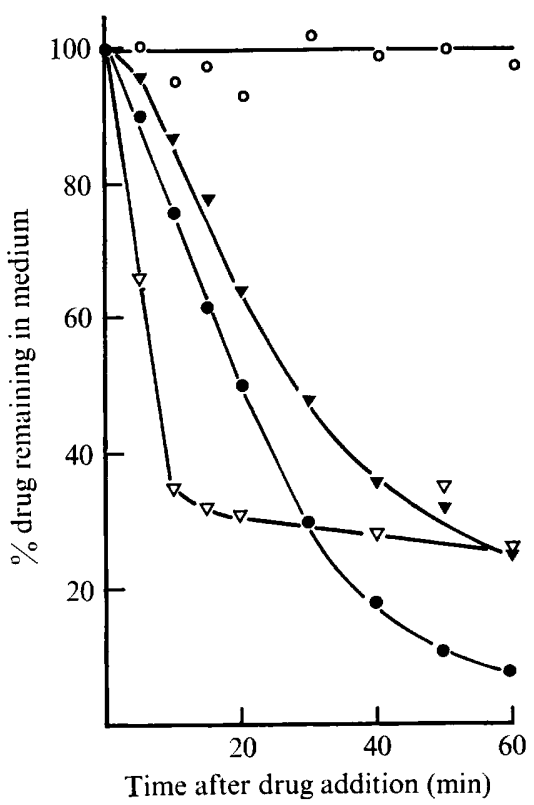

Fig. Io

Fig. 9. Activation of MEV by sensitive and $n d r$ strains of $E$. coli. O, L694 (sensitive); $\times$, L700 (ndr-IOI). The concentration of MEV remaining in the medium was determined spectrophotometrically.

Fig. Io. Metabolism of nitroimidazoles and nitrofurans by E. coli. Strain L694, growing without agitation, was exposed to $0 \cdot 1 \mathrm{mM}$ nitrofurazone $(\nabla), \mathrm{MEV}(\odot)$, azomycin $(\nabla)$ or metronidazole (O). At the time of drug addition $E_{590}$ was 0.2 .

cell density in non-aerated cultures (Fig. 8c). The need for cycles of enrichment (method I) or for indirect selection (method 2) in the isolation of $n d r$ mutants, is presumably due to the low selective advantage of the $n d r$ genotype in the dense cultures normally used when looking for rare mutants.

When grown with vigorous aeration (permitting full expression of resistance) $n d r$ mutants did not metabolize MEV (Fig. 9). This suggests that the mutations might affect either regulation of nitro-organic metabolism, or the activity of one of several enzymes which catalyse 


\section{Table 5. Map location of ndr-150}

Data are from a conjugation between strain L726 (Hfr KLI6 ndr-I 50) and strain L694 (F $\mathrm{F}^{-}$pro A lac tsx supE gal his str); selection was for Pro ${ }^{+}$Str. Recombinant classes are ordered according to the distance of the unselected markers from proA (Taylor \& Trotter, 1972).

\begin{tabular}{|c|c|c|}
\hline $\begin{array}{l}\text { Recombinant } \\
\text { class }\end{array}$ & Number & $\begin{array}{c}\text { Percentage } \\
\text { that were } \\
n d r\end{array}$ \\
\hline pro $^{+}$ & 103 & 20 \\
\hline pro $^{+}$lac $^{+}$ & $8 \mathrm{I}$ & $2 \mathrm{I}$ \\
\hline pro $^{+}$ts $x^{+}$ & 56 & 25 \\
\hline pro $^{+}$sup $^{+}$ & 3 I & 48 \\
\hline pro $^{+} \mathrm{gal}^{+}$ & 24 & 63 \\
\hline pro $^{+} n d r$ & 2 I & - \\
\hline pro $^{+}$his ${ }^{+}$ & 33 & 36 \\
\hline
\end{tabular}

the reduction under different physiological conditions. The $n d r$ mutants were resistant to a variety of nitroimidazoles and nitrofurans (Table 4 ), indicating that these drugs are probably activated by the same system. The mutants had normal sensitivities to structurally unrelated drugs, including mitomycin $\mathrm{C}$ and nalidixic acid, and to u.v. light which interfere with DNA synthesis (Table 4). By m.i.c. determination, we found strain L744 (ndr-3 recAI) to be 100 times more sensitive to MEV than strain $\mathrm{L} 739$ (isogenic $n d r-3 \mathrm{rec}^{+}$) and 40 times more resistant than strain $\mathrm{L} 740$ ( $n d r+r e c A I)$. The u.v.-sensitivities of these strains correlated only with their $r e c$ genotypes, while MEV activation correlated only with their $n d r$ genotypes.

Mutants of $E$. coli conditionally resistant to nitrofurazone have also been reported (Asnis, Cohen \& Gots, I952). These mutants are probably similar to $n d r$, as they were deficient in nitrofurazone reduction. Another class of nitrofuran-resistant mutants was isolated in E. coli B (Szybalski \& Nelson, 1954; McCalla, 1965) and in E. coli s (WoodyKarrer \& Greenberg, I963); these behaved like u.v.-resistant derivatives of the hypersensitive parental strains. We observed that MEV was a suitable selective agent for $\mathrm{Rec}^{+}$revertants of strain $\mathrm{L} 354$. Derivatives of $E$. coli $\mathrm{B} / \mathrm{r}$ that showed higher resistance to nitrofuran (Payne et al., 1956; McCalla et al., I970) could be similar to $n d r$.

Mapping of $n d r$ mutations was complicated by the necessity for indirect selection of resistant recombinants and by the absence of easily selected nearby markers. Six $n d r$ mutations ( $n d r-10 I, n d r-150, n d r-3$ and three mutants with low resistance selected by direct plating of $\mathrm{L} 674$ on NB agar containing $0.13 \mathrm{~mm}$-MEV) were mapped in the gal region by conjugation. However, we did not observe PI-mediated cotransduction of $n d r$ with gal. Data for the mapping of $n d r-150$ is shown in Table 5 .

Among the known $E$. coli markers in the gal region are several of the $c h l$ series which control inorganic nitrate reduction (Venables \& Guest, 1968). .Our $n d r$ mutants were all $c h l^{+}$by the plate test of Glaser \& DeMoss (I97I), and several chl mutants tested (strains L490, L714, L716 and L725) metabolized MEV normally and had wild-type sensitivity to nitrodrugs. Thus, inorganic nitrate and nitro-organic reduction have at least partially independent enzymic pathways in $E$. coli.

\section{Correlation of antimicrobial activity of nitroimidazoles and nitrofurans with their reducibility}

Different nitro-heterocyclic antimicrobial drugs appear to have the same mechanism of action as MEV, as shown by the cross-resistance of strains selected for resistance to MEV (Table 4) and the hypersensitivity of $\operatorname{recA}$ strains to these drugs (Yahagi et al., I974; Gold- 


\section{Table 6. Relationship between $E_{\frac{1}{2}}$ and spectrum of antimicrobial activity of nitro-drugs}

Values of $E_{\frac{1}{2}}$ were measured relative to a saturated calomel electrode. Where lower lim its of activity are given, insolubility of the drug was the usual reason for failure to test higher concentrations.

\begin{tabular}{|c|c|c|c|c|}
\hline \multirow[b]{2}{*}{ Drug } & \multirow[b]{2}{*}{$\begin{array}{c}E_{\frac{1}{2}} \\
(\mathrm{mV})\end{array}$} & \multicolumn{2}{|c|}{ M.i.c. (mM) } & \multirow[b]{2}{*}{ (I) $/(2)$} \\
\hline & & E. coli $\mathrm{L} 47$ & $\begin{array}{c}T . \\
\text { (2) }\end{array}$ & \\
\hline LI0997 & -165 & 0.2 & $>0.4$ & $<0.5$ \\
\hline L7373 & -195 & $0 . I$ & $>0.5$ & $<0.2$ \\
\hline L945I & -210 & 0.05 & 0.5 & $0 \cdot I$ \\
\hline L87 I I & -230 & 0.1 & 0.6 & 0.17 \\
\hline Furazolidone & -275 & 0.004 & & \\
\hline Nitrofurazone & -278 & 0.01 & & \\
\hline LI 2376 & -345 & 0.3 & 0.05 & 6 \\
\hline MEV & -355 & 0.03 & 0.007 & 4 \\
\hline LI 2 I 34 & -374 & 2 & 0.03 & 67 \\
\hline LI 24 I 5 & -400 & $>0.6$ & 0.001 & $>600$ \\
\hline L6347 & -400 & 3 & 0.06 & 50 \\
\hline L6678 & -435 & $>2$ & $0 \cdot I$ & $>20$ \\
\hline L5553 & -443 & $>I$ & 0.04 & $>25$ \\
\hline Azomycin & -470 & 0.2 & 0.004 & 50 \\
\hline LI 2407 & -470 & $>0.5$ & 0.003 & $>160$ \\
\hline LI 2375 & -497 & 2 & 0.1 & 20 \\
\hline Metronidazole & -500 & 4 & 0.003 & I 200 \\
\hline
\end{tabular}

Table 7. Comparative activities of nitroimidazoles and aminoimidazoles

\begin{tabular}{|c|c|c|c|c|}
\hline \multirow[b]{2}{*}{ Compound } & \multicolumn{3}{|c|}{ Structure (see Table I) } & \multirow{2}{*}{$\begin{array}{l}\text { M.i.c. (mM) for } \\
\text { T. vaginalis }\end{array}$} \\
\hline & $\mathbf{R}$ & $\mathbf{R}^{\prime}$ & $\mathbf{R}^{\prime \prime}$ & \\
\hline $\begin{array}{l}\mathrm{L} 6347 \\
\mathrm{~L} 6602 . \mathrm{HCl}\end{array}$ & $\begin{array}{l}\mathrm{CH}_{3} \\
\mathrm{CH}_{3}\end{array}$ & $\begin{array}{l}\mathrm{NO}_{2} \\
\mathrm{NH}_{2}\end{array}$ & $\begin{array}{l}\text { iso- } \mathrm{C}_{3} \mathrm{H}_{7} \\
\text { iso- } \mathrm{C}_{3} \mathrm{H}_{7}\end{array}$ & $>13$ \\
\hline $\begin{array}{l}\mathrm{L} 6678 \\
\mathrm{~L} 672 \mathrm{I} . \mathrm{HCl}\end{array}$ & $\begin{array}{l}\mathrm{HOCH}_{2} \mathrm{CH}_{2} \\
\mathrm{HOCH}_{2} \mathrm{CH}_{2}\end{array}$ & $\begin{array}{l}\mathrm{NO}_{2} \\
\mathrm{NH}_{2}\end{array}$ & $\begin{array}{l}\mathrm{CH}_{3} \\
\mathrm{CH}_{3}\end{array}$ & $\begin{aligned} & 0.1 \\
> & I 4\end{aligned}$ \\
\hline $\begin{array}{l}\text { L5553 } \\
\text { L5541. } \mathrm{HCl}\end{array}$ & $\begin{array}{l}\mathrm{CH}_{3} \\
\mathrm{CH}_{3}\end{array}$ & $\begin{array}{l}\mathrm{NO}_{2} \\
\mathrm{NH}_{2}\end{array}$ & $\begin{array}{l}\mathrm{CH}_{3} \\
\mathrm{CH}_{3}\end{array}$ & $\begin{array}{l}0.04 \\
>20\end{array}$ \\
\hline $\begin{array}{l}\text { Azomycin } \\
\text { L5130.HCl }\end{array}$ & $\begin{array}{l}\mathbf{H} \\
\mathbf{H}\end{array}$ & $\begin{array}{l}\mathrm{NO}_{2} \\
\mathrm{NH}_{2}\end{array}$ & $\begin{array}{l}\mathbf{H} \\
\mathbf{H}\end{array}$ & $>24^{0.004}$ \\
\hline
\end{tabular}

stein et al., 1977). The abilities of different nitro-heterocyclic drugs to inhibit the growth of $E$. coli correlated with their rates of metabolic conversion by this organism. Figure Io compares the rates of disappearance of four different drugs from $E$. coli cultures. Nitrofurazone was the most rapidly metabolized of the four, followed by $\mathrm{MEV}$, azomycin and metronidazole. As can be seen from Table 6, their rates of metabolism correlated with their effectiveness against $E$. coli. The values of $E_{\frac{1}{2}}$ (Table 6) correlated with both of these parameters; the lower the $E_{\frac{1}{2}}$ of a drug, the less rapidly was it metabolized by $E$. coli and the less effective it was. Metronidazole, which has a very low $E_{\frac{1}{2}}$, was neither metabolized by $E$. coli (Fig. I0) nor active against this organism (Table 6).

We assayed a number of nitro-drugs for their anti-coli and anti-trichomonal activity. When these compounds were ordered by increasingly negative $E_{1}$ (Table 6), we observed that those drugs whose $E_{\frac{1}{2}}$ was more negative than $-370 \mathrm{mV}$ (with the sole exception of azomycin) showed little activity against $E$. coli, a facultative anaerobe. However, all of the 
drugs were quite active against two obligate anaerobes, $T$. vaginalis (Table 6) and Clostridium perfringens (data not shown). This relationship is more clearly illustrated by limiting comparison to three isomeric pairs of nitroimidazoles in which the 2- and 5-substituents are interchanged (L945I/Lr2376; L87 I I/LI2375; Lr2134/LI2407; see Table I). The 5-nitroimidazoles all had lower $E_{\frac{1}{2}}$ than the corresponding 2-nitro isomers; the former were less active against $E$. coli and more active against $T$. vaginalis than their isomers.

From these data, one may conclude that a necessary (if not sufficient) condition for the activity of nitro-drugs is that they be reduced at the redox potential present in cultures of the target organisms, as already suggested by Dann \& Möller (1949) for nitrofurans and nitrothiophenes. However, certain discordant observations must be explained: the culture medium of MEV-treated $E$. coli had an antimicrobial titre equal to the remaining unreduced MEV (data not shown); bacteriophage $\mathrm{T}_{4}$ bo5 was not inactivated by incubation in the presence of $\mathrm{T}_{4}$-resistant bacteria (incapable of adsorbing the phage) which were metabolizing the drug (data not shown); compounds with less negative $E_{\frac{1}{2}}$ were relatively inactive against $T$. vaginalis (Table 6).

The explanation for these observations may be due to the final reduction products of nitro-drugs (the amino-derivatives) being inactive. This is illustrated in Table 7 , in which the activities of four pairs of nitro- and aminoimidazoles are compared. Dann \& Möller (1947, I949) had similarly observed that aminothiophenes and aminofurans were inactive. It is probable that the reactive forms of all of these drugs are partially reduced intermediates which are highly unstable; likely candidates are the hydroxylamino- or nitroso-derivatives (Dann \& Möller, 1949; Paul et al., 1960; McCalla et al., 1970). Thus, the metabolites of $\mathrm{MEV}$ in the medium of treated cells were probably not the reactive compounds. We consider that this accounts for the behaviour of all the nitro-drugs studied, with the possible exception of azomycin, which may have a second mechanism of action (unpublished observations).

We would like to thank Mr G. Sartori who provided the $\left[{ }^{14} \mathrm{C}\right] \mathrm{MEV}$; Mr P. Gironi who performed the polarographicanalysis; Professor G. Lancini and Drs G. Gallo, M. Kohiyama, G. Mastromei, G. Pelizza, and S. Riva for helpful discussions; and, in particular, Dr E. Nielsen who was actively involved in the initial phases of this work.

\section{REFERENCES}

Asnis, R. E., Cohen, F. B. \& Gots, J. S. (1952). Studies on bacterial resistance to furacin. Antibiotics and Chemotherapy 2, I 23-I 29.

Assandri, A., Lancini, G. C., Volpe, G. \& Cavalleri, B. (1976). New nitroimidazole derivative with antibacterial activity. Belgian Patent 837,595 .

Bambury, R. E., Lutz, C. M., Miller, L. F., Kim, H. K. \& Ritter, H. W. (I973). Nitrones. 6. $\alpha$-(5Nitroimidazol-2-yl)- $N$-substituted nitrones. Journal of Medicinal Chemistry 16, 566-568.

Becket, A. H. \& Robinson, A. E. (1956). The reactions of antibacterial substances with bacteria. Part I. Methods using nitrofurazone and Aerobacter aerogenes. Journal of Pharmacy and Pharmacology 8, 1072-1085.

Beckett, A. H. \& Robinson, A. E. (1959). The reactions of nitrofurans with bacteria. II. Reduction of a series of nitrofurans by Aerobacter aerogenes. Journal of Medicinal and Pharmacological Chemistry $\mathbf{r}$, I35-I 54 .

Brezina, M. \& Zuman, P. (1958). Polarography in Medicine, Biochemistry and Pharmacy. New York: Interscience.

Brown, N. C., Wisseman, C. L. III \& Matsushita, T. (1972). Inhibition of bacterial DNA replication by 6-(p-hydroxyphenylazo)-uracil. Nature New Biology 237, 72-74.

BuRgess, R. R. (1969). A new method for the large scale purification of Escherichia coli deoxyribonucleic acid-dependent ribonucleic acid polymerase. The Journal of Biological Chemistry 244, 6I60-6I67.

CARTwright, N. J. \& CAIN, R. B. (1959). Bacterial degradation of the nitrobenzoic acids. 2. Reduction of the nitro group. Biochemistry 73, 305-314. 
Cavalleri, B., Ballotta, R. \& ARIoli, V. (I97I). Schiff bases from 2-aminoimidazoles. Chimie Therapeutique 6, 397-402.

Cavalleri, B., Ballotta, R. \& Lancini, G. C. (1972). Synthesis of I-alkyl-2-nitroimidazole-5-carboxaldehydes. Journal of Heterocyclic Chemistry 9, 979-984.

Cavalleri, B., Ballotta, R., Arioli, V. \& Lancini, G. C .(1973). New 5-substituted I-alkyl-2-nitroimidazoles. Journal of Medicinal Chemistry 16, 557-560.

Cavalleri, B., Arioli, V. \& LaNCINI, G. C. (1974). Synthesis and antimicrobial activity of 2-nitroimidazoles substituted in position 5. Progress in Chemotherapy, Proceedings of the Eighth International Congress of Chemotherapy (Athens, 1974), vol. 2, pp. 560-565. Edited by G. K. Daikos. Athens: Hellenic Society for Chemotherapy.

Cavalleri, B., Ballotta, R. \& Arioli, V. (1975). I-alkyl-2-nitroimidazol-5-yl derivatives. ArzneimittelForschung 25, 338-340.

Clark, A. J., Chamberlin, M., Boyce, R. P. \& Howard-Flanders, P. (1966). Abnormal metabolic response to ultraviolet light of a recombination deficient mutant of Escherichia coli K12. Journal of Molecular Biology 19, 442-454.

Cramer, D. L. (1947). Mode of action of nitrofuran compounds. II. Application of physicochemical methods to the study of action against Staphylococcus aureus. Journal of Bacteriology 54, 1 19-1 25.

DANN, O. \& MöLLER, E. F. (1947). Bakteriostatisch wirkende Nitro-Verbindungen des Thiophens und Furans. Chemische Berichte 80, 23-36.

DANN, O. \& MöLlER, E. F. (1949). Uber die wachstumshemmenden Eigenschaften von Nitroverbindungen. Chemische Berichte 82, 76-94.

Davis, B. D. \& Mingioli, E. S. (1950). Mutants of Escherichia coli requiring methionine or vitamin B12. Journal of Bacteriology 60, 1 7-28.

Edwards, D. I., Dye, M. \& CARNe, H. (1973). The selective toxicity of antimicrobial nitroheterocyclic drugs. Journal of General Microbiology 76, 135-145.

Glaser, J. H. \& DeMoss, J. A. (1971). Phenotypic restoration by molybdate of nitrate reductase activity in chlD mutants of Escherichia coli. Journal of Bacteriology 108, 854-860.

Goldstein, B. P., Nielsen, E., Berti, M., Bolzoni, G. \& Silvestri, L. G. (1977). The mechanism of action of nitro-heterocyclic antimicrobial drugs. Primary target of I-methyl-2-nitro-5-vinylimidazole is DNA. Journal of General Microbiology 100, 271-281.

GRUNBERG, E. \& TITSWORTH, E. H. (1973). Chemotherapeutic properties of heterocyclic compounds: monocyclic compounds with five-membered rings. Annual Reviews of Microbiology 27, 317-346.

HeNRY, D. W. \& HoFF, D. R. (1965). I-Substituted-2-acyl-5-nitroimidazoles. Belgian Patent 66r, 262.

Hoffer, M. \& MacDonald, A., Jr (1972). I-Methyl-2-substituted 5-nitroimidazoles. U.S. Patent $3,652,579$.

IngS, R. M. J., McFadzean, J. A. \& Ormerod, W. E. (I974). The mode of action of metronidazole in Trichomonas vaginalis and other microorganisms. Biochemical Pharmacology 23, I42I-I429.

KohiYama, M. \& Kolber, A. R. (1970). Temperature sensitive mutant of the DNA replication system in Escherichia coli. Nature, London 228, $1157-1160$.

Kolthoff, J. M. \& LiNGANE, J. J. (1952). Polarography. New York: Interscience.

LANCINI, G. C. \& LAzZARI, E. (I965). The synthesis of azomycin. Experientia 2I, 83.

Lancini, G. C., Lazzari, E., Arioli, V. \& Bellani, P. (I969). Synthesis and relationship between structure and activity of 2-nitroimidazole derivatives. Journal of Medicinal Chemistry 12, 775-780.

Lawson, A. (1956). The reaction of cyanamide with $\alpha$-amino-acetals and $\alpha$-amino-aldehydes. Journal of the Chemical Society, 307-310.

MCCALLA, D. R. (1965). Nitrofuran derivatives as radiomimetic agents: cross-resistance studies with Escherichia coli. Canadian Journal of Microbiology II, 185-19I.

MCCALlA, D. R., Reuvers, A. \& KAiser, C. (1970). Mode of action of nitrofurazone. Journal of Bacteriology IO4, II 26-II 34.

MilleR, J. H. (1972). Experiments in Molecular Genetics. Cold Spring Harbor: Cold Spring Harbor Laboratory.

Paul, H. E., Ells, V. R., KopKo, F. \& Bender, R. C. (1960). Metabolic degradation of the nitrofurans. Journal of Medicinal and Pharmaceutical Chemistry 2, 563-584.

Payne, J. I., Hartman, P. E., Mudd, S. \& Phillips, A. W. (1956). Cytological analysis of ultravioletirradiated Escherichia coli. III. Reactions of a sensitive strain and its resistant mutants. Journal of Bacteriology 72, 461-472.

SAeKi, T., UmezaWA, H., Tokieda-Fujishige, T. \& HerI, M. (1974). Biological effects of azomycin (2-nitroimidazole): inhibition of ribonucleoside reductase. Journal of Antibiotics 27, 225-227.

SzYbalski, W. \& Nelson, T. C. (1954). Genetics of bacterial resistance to nitrofurans and radiation. Bacteriological Proceedings 1954, 5I-52.

TAYLOR, A. L. \& TrOTTER, C. D. (1972). Linkage map of Escherichia coli strain KI2. Bacteriological Reviews 36, 504-524.

TU, Y. \& MCCALla, D. R. (1975). Effect of activated nitrofurans on DNA. Biochimica et biophysica acta 402, I42-I49. 
Venables, W. A. \& Guest, J. R. (1968). Transduction of nitrate reductase loci of Escherichia coli by PI and $\lambda$. Molecular and General Genetics 103, $127-140$.

WimpenNY, J. W. T. \& Cole, J. A. (1967). The regulation of metabolism in facultative bacteria. III. The effect of nitrate. Biochimica et biophysica acta 148, 233-242.

WoOdy-KARRER, P. \& GreEnBerg, J. (1963). Resistance and cross-resistance of Escherichia coli s mutants to the radiomimetic agent nitrofurazone. Journal of Bacteriology 85, I 208-1 216.

Yahagi, T., Nagao, M., Kazuko, H., Matsushima, T., Sugimura, T. \& Byran, G. T. (1974). Relationships between the carcinogenic and mutagenic or DNA-modifying effects of nitrofuran derivatives, including 2-(2-furyl)-3-(5-nitro-2-furyl)acrylamide, a food additive. Cancer Research 34, 2266-2273. 